\title{
Snowflakes and seaweed
}

\author{
Denis Weaire, Trinity College, University of Dublin, Ireland
}

Sometime around 1609 Johann Kepler $S$ caught what he described as a star from heaven, an individual snowflake. Its elegant shape inspired him to write $A$ New Year's Gift or the Six-Cornered Snowflake for his benefactor, Counsellor Wackher of Regensburg. It was a minor diver-

tissement in his illustrious career, but a remarkable one. For some it even represents the origin of crystallography.

In his essay Kepler rambled amusingly from the seeds of the pomegranate to the cells of the honeybee, picking up clues to the origin of symmetric natural structures. He was led to a theory for the sixfold shape of the snowflake in terms

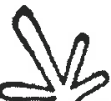
$2 \sqrt{2}$
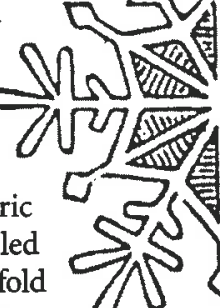
of the packing of tiny lumps of ice. These were not described as atoms, but played the same role of simple, primary constituents, out of which a complex pattern was to arise.

The same indescribable beauty was admired by the Irish physicist John Tyndall in the 19th century. How imperfect seem the productions of human minds and hands when compared with those formed by the blind forces of nature! But the blindness is ours, said Tyndall, although he correctly attributed the sixfold shape to the way in which molecules of $\mathrm{H}_{2} \mathrm{O}$ are arranged in the crystalline structure of ice. In his book on Forms of Water, largely drawn from his mountaineering experiences in Switzerland, he also gives an account of flowers of ice in frozen lakes, which have a similar sixfold shape. They are formed when sunlight melts the surface of the ice.

Only in recent times was the snowflake adopted as the universal icon of a white Christmas. The earliest example of its use in art is said to be on a $19^{\text {th }}$ century Japanese sword-guard, but the ancient Chinese certainly knew all about snowflakes, so this assertion may well be wrong by some thousands of years!

The snowflake's star poses a further question. Why does it branch out, in a manner reminiscent of plants? Today we can understand this too, as a consequence of the growth process in which water vapour freezes on the growing flake. Depending on the precise conditions, such processes may lead to compact rounded objects, or branching feathery ones, in socalled dendritic growth. If several generations of branches are involved, we may even approach the mathematicians ideal of a fractal structure, one in which detail is contained with detail, indefinitely.

In branching out and tending towards towards a fractal structure, the snowflake maintains its symmetry, more or less. When similar patterns were first found in metals they were called iron snow. But other growth processes lead to more random structures, rather like seaweed in appearance. Treasa Meegan has just completed a $\mathrm{PhD}$ in the TCD Physics Department, modelling these structures and comparing her computer simulations with patterns found when metals are electrodeposited. These patterns are found to swirl clockwise or counter-clockwise when magnetic fields are applied, and the research group of Michael Coey hopes to exploit these magnetic effects. They may have important implications for the practical use of electrodeposition in industry.

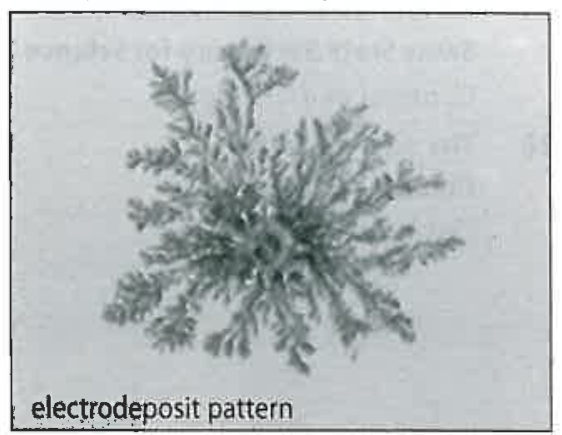

Treasa is currently starring as Snow White in Ireland's leading Christmas pantomime (a traditional form of popular seasonal entertainment), and may be lost to science if her budding acting career prospers. One wonders what Grumpy's remark would be, on being told that his guest is a computational physicist.

[Adapted with permission from an article in the Irish Times]

\section{Editorial Advisory Board}

Chairman George Morrison, Alexis Baratoff, JeanPatrick Connerade, Carlos Fiolhais, Bill Gellietly, Frank Israel, Marie-Claude Lemaire, Peter Oelhafen, Jens Olaf Pepke Pederson, Christophe Rossel, Claude Sébenne, Marshall Stoneham, Wolfiam von Oertzen, Jean-Marc Quilbé

\section{Advertising Manager Susan Mackie}

Address 250 , rue Saint-Jacques, 75005 Paris, France tel $+33155428051 \mathrm{fax}+33146332106$ email mackie@edpsciences.org

Production Manager Agnes Henri

Address EDP Sciences, 17 avenue du Hoggar, BP 112 PA de Courtabceuf, F-91944 Les Ulis Cedex A, France tel +33169187575 fax +33169288491

Printer Rotofrance, Lognes, France

Dépot légal: janvier 2002

\section{Schedule}

Six issues will be published in 2002. The magazine is distributed in the second week of January, March, May, July, September, November. A directory issue with listings of all EPS officiais is published once a year.

\section{Subscriptions}

Individual Ordinary Members of the European Physical Society receive europhysics news free of charge. Members of EPS National Member Societies receive europhysics news through their society, except members of the Institute of Physics in the United Kingdom and the German Physical Society who receive a bimonthly bulletin. The following are subscription prices available through EDP Sciences. Institutions 600 French francs or 91 euros (VAT included, European Union countries); 600 French francs or 91 euros (the rest of the world). Individuals 380 French francs or 58 euros (VAT included, European Union countries); 380 French francs or 58 euros (the rest of the world). Contact subscribers@edpsciences.com or visit www.epdsciences.com. 